CLINICAL STUDY

\title{
Evaluation of endocrine testing of Leydig cell function using extractive and recombinant human chorionic gonadotropin and different doses of recombinant human LH in normal men
}

\author{
Anne Cailleux-Bounacer, Yves Reznik ${ }^{2}$, Bruno Cauliez ${ }^{1}$, Jean François Menard, Céline Duparc and Jean Marc Kuhn \\ Department of Endocrinology and INSERM CIC 204, Rouen University Hospital, 76000 Rouen, France, ${ }^{1}$ Department of Hormonal Biochemistry, 76000 \\ Rouen, France and ${ }^{2}$ Department of Endocrinology, Caen University Hospital, 14000 Caen, France \\ (Correspondence should be addressed to J M Kuhn who is now at Department of Endocrinology, Hôpital de Bois Guillaume, 147 Avenue du Maréchal Juin, \\ 76230 Bois Guillaume, France; Email: jean-marc.kuhn@chu-rouen.fr)
}

\begin{abstract}
Background: The functional testing of endocrine testis uses extractive human chorionic gonadotropin (ehCG). Recombinant human hCG (rhCG), avoiding any contamination, should replace ehCG. Moreover, a functional evaluation with recombinant human LH (rhLH) would be closer to physiology than a pharmacological testing with hCG.

Methods: The study was conducted in normal men. We first evaluated the dose-effect of ehCG on plasma testosterone and estradiol levels, before and after injection of either hCG or vehicle. Secondly, the responses to the optimal dose of ehCG were compared with those of rhCG. Thirdly, we investigated the dose-effect of rhLH, on steroid hormone secretion. LH, testosterone, and estradiol plasma levels were measured after the injection of either rhLH or placebo.

Results: ehCG induced dose-dependent increases in plasma estradiol and testosterone levels. They respectively peaked at 24 and $72 \mathrm{~h}$ after the injection. The most potent dose of ehCG (5000 IU) induced results similar to those observed with $250 \mu \mathrm{g}$ (6500 IU) rhCG. By comparison with placebo, rhLH induced a significant and dose-dependent increase in plasma testosterone levels $4 \mathrm{~h}$ after the injection. Peak response of testosterone to rhLH and rhCG was significantly correlated. rhLH did not induce significant change in plasma estradiol level.

Conclusions: In normal men, a single i.v. injection of $150 \mathrm{IU}$ rhLH induces a $25 \%$ rise in plasma testosterone levels by comparison with placebo. At the moment, the dynamic evaluation using hCG remains the gold standard test to explore the Leydig cell function. The use of $250 \mu \mathrm{g}$ rhCG avoiding any contamination should be recommended.
\end{abstract}

European Journal of Endocrinology 159 171-178

\section{Introduction}

In normal adult men, steroid hormone secretion by the Leydig cell is physiologically regulated by luteinizing hormone (LH). The gonadotropin acts through the stimulation of a G-protein-coupled receptor positively linked to adenylyl cyclase and exclusively expressed by the interstitial Leydig cells. In adult man, the activation of this receptor adenylyl cyclase system induces the synthesis and the secretion of testosterone $(\mathrm{T})$ and estradiol $\left(\mathrm{E}_{2}\right)$. During puberty, the gonadotrophin-releasing hormone (GnRH)-induced pulsatile release of follicle-stimulating hormone (FSH) is responsible for the increase in testis volume. Simultaneously, LH pulses induce a progressive rise in plasma $\mathrm{T}$ and $\mathrm{E}_{2}$ levels. Human chorionic gonadotropin (hCG) is able to stimulate sex steroid secretion by the testis through the activation of the same receptor of the Leydig cell membrane, rightly named $\mathrm{LH} / \mathrm{hCG}$ receptor. In contrast to $\mathrm{LH}$, hCG was easily available from the urine of pregnant women. hCG has a long plasma half life $(1,2)$ and induces a sustained and prolonged stimulation of Leydig cell steroidogenesis $(3,4)$. For this reason, hCG was used as a treatment of various testicular diseases including cryptorchid testes (5-7), male hypogonadotropic hypogonadism (8), and in association with human menopausal gonadotropin, male infertility $(9,10)$. On the other hand, hCG testing of Leydig cell function was of interest for the search of the presence of intra-abdominal testes in case of bilateral ectopia $(6,7)$, for differentiating delayed puberty from hypogonadotropic hypogonadism (11-13), and for the etiological diagnosis of gynecomastia $(14,15)$. Various modalities of testing have been proposed in terms of hCG doses, the number of injections, and times of blood drawing $(3,11,13,16)$. The widely used hCG testing of Leydig cell function in adulthood is performed with one injection of 5000 IU hCG and measurements of plasma T and $E_{2}$ before and every morning of the 3 days following the injection (12,17-19). The availability of recombinant human gonadotropins, which allows avoidance of the 
potential risk of pathogenic agent transmission, enables elaboration of new modalities of endocrine testicular testing. The aim of the present study was: i) to evaluate the effect of different doses of extractive hCG (ehCG) on the steroidogenic response of the testis, ii) to compare the optimal dose of ehCG with that of rhCG on the same parameters, and iii) with the reference of results of hCG stimulation, to investigate a Leydig cell response to tests with different doses of recombinant human LH (rhLH) injected intravenously in order to obtain a fast steroidogenic response.

\section{Subjects and methods}

\section{Subjects studied and protocols}

Twenty adult men were included in this randomized single-blind study that was approved by the Institutional Ethic Committee of Basse Normandie, France. The subjects who gave their informed consent to the study protocol were divided into two groups.

Group I The first group included eight normal men (aged 18-30). They were taking no medication and did not have any history of disease or infertility. They were recruited from the list of healthy volunteers of the Clinical Investigation Center (INSERM 0204). Clinical examination including the BMI $\left(20-24 \mathrm{~kg} / \mathrm{m}^{2}\right)$ was normal. All hormone parameters (including basal and GnRH-stimulated gonadotropins, basal, and hCGstimulated testosterone $(\mathrm{T})$ and estradiol $\left(\mathrm{E}_{2}\right)$, sex hormone-binding globulin (SHBG), and plasma inhibin B) were normal.

Blood was drawn in order to measure basal morning (0800 h) plasma $\mathrm{T}$ and $\mathrm{E}_{2}$ levels. Then, either vehicle alone or a dose $(50,500$, or 5000 IU) of hCG (Organon SA, Puteaux, France) was infected. Its stated potency was $2500 \mathrm{IU} / \mathrm{mg}$ in terms of the first International Reference Reagent (IRR) 99/688. hCG doses were injected intramuscularly in a random order. Blood was withdrawn 1,3 , and $5 \mathrm{~h}$ later and then every morning for 3 days $(24,48$, and $72 \mathrm{~h}$ after the injection) to determine $\mathrm{T}$ and $\mathrm{E}_{2}$ in response to the stimulation. A 2-week interval separated each step of the study.

Group II The second group included 12 normal men (aged 18-30) who responded to similar criteria as in group I. They were recruited from the list of healthy volunteers of the Clinical Investigation Center (INSERM 0204) and from the healthy volunteers recruited in Caen University Hospital. Clinical examination of the BMI (20-24 kg/m²) was normal. All hormone parameters (including basal and GnRH-stimulated gonadotropins, basal and hCG-stimulated $\mathrm{T}$ and $\mathrm{E}_{2}$, SHBG, and plasma inhibin B) were normal. The study comprised six steps, each separated by 2 weeks.
In the first step, blood was drawn in order to measure basal morning $(0800 \mathrm{~h})$ plasma $\mathrm{T}$ and $\mathrm{E}_{2}$ levels. Then, 5000 IU extractive ehCG, (Organon SA, Puteaux, France) were injected intramuscularly, and the blood was subsequently withdrawn every morning for 3 days to determine $\mathrm{T}$ and $\mathrm{E}_{2}$ levels in response to the stimulation.

During the four following steps, after a basal blood sampling $(0800 \mathrm{~h})$ either vehicle or a dose $(75,150$, or $225 \mathrm{IU}$ ) of recombinant human LH (rhLH, Luveris, Serono-France, Boulogne, France) was infected in which the stated potency was $18187 \mathrm{IU} / \mathrm{mg}$ in terms of the second International RP (IRP) 80/552 (20). rhLH doses were injected intravenously in a random order. Then, the blood was withdrawn at the following times $(30,60,90,120,150,180,240$, and $300 \mathrm{~min})$ in order to measure $\mathrm{LH}, \mathrm{T}$, and $\mathrm{E}_{2}$ plasma levels.

The last step of the study was performed similarly to the first one but used 6500 IU rhCG, (Ovitrelle, SeronoFrance, Boulogne, France). Its stated potency was $26000 \mathrm{IU} / \mathrm{mg}$ in terms of the first IRR 99/688.

\section{Hormone assays}

LH, FSH, hCG, and SHBG were measured by their respective chemiluminescent assays (Immulite 2500, Siemens Diagnostics, La Garenne Colombe, France). Plasma LH assay was calibrated according to first IRP 68/40 and second IRP 80/552. Plasma T was assayed after organic extraction. Plasma T levels measured by RIA (testosterone RIA, Immunotech, Beckman-Coulter, Villepinte, France). Normal ranges of adult men were $T=10.4-34.5 \mathrm{nmol} / \mathrm{l}$. E $\mathrm{E}_{2}$ was measured by RIA (estradiol RIA, Diasorin SA, Antony, France). Normal values in adult men were below $157 \mathrm{pmol} / \mathrm{l}$. Inter-assay imprecision (coefficient of variation) is 8.2 and $4.6 \%$ for $\mathrm{T}($ mean value $=11.9 \mathrm{nmol} / \mathrm{l})$ and $\mathrm{E}_{2}($ mean value $=$ $345 \mathrm{pmol} / \mathrm{l})$ respectively.

\section{Statistical analysis}

Statistical analysis used an ANOVA with three parameters: subject, treatment, and time of blood drawing. As to whether this first step of analysis evidenced a difference in the evolution with time of these parameters, a new analysis was done either with constant time or constant treatment using Student's t-test with the correction of Bonferroni. The relationships between the dose of treatment and the hormone responses observed were studied with Pearson's correlation test. A similar analysis was performed to evaluate the relationships between the peaks of testosterone obtained in the various conditions of testing. Statistical differences were evaluated by applying Student's $t$-test for unpaired and paired data as appropriate. Comparisons were noted statistically significant at an $\alpha$-level of less than 0.05 . 
Table 1 Basal and peak values of plasma testosterone and estradiol (mean \pm S.E.M.) in normal men (group I) in response to the injection of vehicle alone or 50, 500, and $5000 \mathrm{IU}$ extractive human chorionic gonadotropin (ehCG).

\begin{tabular}{lcccr}
\hline & $\begin{array}{c}\text { Testosterone base } \\
(\mathrm{nmol} / \mathrm{l})\end{array}$ & $\begin{array}{c}\text { Testosterone peak } \\
(\mathrm{nmol} / \mathrm{l})\end{array}$ & Estradiol base (pmol/l) & Estradiol peak (pmol/l) \\
\hline Vehicle & $13.9 \pm 1.8$ & $14.4 \pm 1.8$ & $68.7 \pm 7.3$ & $70.9 \pm 10.3$ \\
50 IU ehCG & $14.0 \pm 1.6$ & $19.2 \pm 2.5$ & $72.7 \pm 4.4$ & $91.8 \pm 16.2$ \\
500 IU ehCG & $13.6 \pm 2.0$ & $23.4 \pm 3.3$ & $67.2 \pm 7.7$ & $143.2 \pm 14.7$ \\
5000 IU ehCG & $13.6 \pm 0.9$ & $26.6 \pm 3.5$ & $76.4 \pm 15.8$ & $260.3 \pm 25.3$ \\
\hline
\end{tabular}

\section{Results}

\section{Group I}

Mean basal plasma $\mathrm{T}$ level was $13.88 \pm 1.84 \mathrm{nmol} / \mathrm{l}$ in the testing using vehicle alone. Similar basal plasma T levels were obtained before the injection of the different doses of ehCG (Table 1). Plasma T did not vary after vehicle injection. By contrast, plasma $\mathrm{T}$ levels peaked to $19.17 \pm 2.50,23.44 \pm 3.29$, and $26.62 \pm 3.47 \mathrm{nmol} / \mathrm{l}$ after the injection of 50, 500, and $5000 \mathrm{IU}$ ehCG respectively. Highest plasma $\mathrm{T}$ levels were observed earlier $(48 \mathrm{~h})$ with 50 and $500 \mathrm{IU}$ than with $5000 \mathrm{IU}$ ehCG injection, where peak was observed at time $+72 \mathrm{~h}$ (Fig. 1). Mean peak values of plasma T observed after each dose of ehCG injection were significantly higher $(P<0.01)$ than their respective basal values. Plasma $\mathrm{T}$ rise after $5000 \mathrm{IU}$ ehCG was significantly higher $(P<0.01)$ than that observed with either 50 or $500 \mathrm{IU}$ ehCG. Plasma T peak with $500 \mathrm{IU}$ was significantly higher $(P<0.01)$ than that observed with 50 IU ehCG.

Mean basal plasma $\mathrm{E}_{2}$ level was $68.65 \pm 7.34 \mathrm{pmol} / \mathrm{l}$ in the testing using vehicle alone. Similar basal plasma $E_{2}$ levels were obtained during each stage of the study (Table 1). They did not significantly change after either vehicle or $50 \mathrm{IU}$ ehCG injection. By contrast, plasma $\mathrm{E}_{2}$ levels increased to $143.17 \pm 14.68$ and $260.27 \pm$ $25.33 \mathrm{pmol} / \mathrm{l}$ after the injection of 500 and $5000 \mathrm{IU}$ ehCG respectively. Highest plasma $\mathrm{E}_{2}$ levels were observed $24 \mathrm{~h}$ after the injection of either 500 or 5000 IU ehCG (Fig. 1). Mean peak values of plasma $\mathrm{E}_{2}$ observed with either 500 or $5000 \mathrm{IU}$ ehCG were significantly higher $(P<0.01)$ than their respective basal values and plasma $\mathrm{E}_{2}$ rise after 5000 IU hCG was
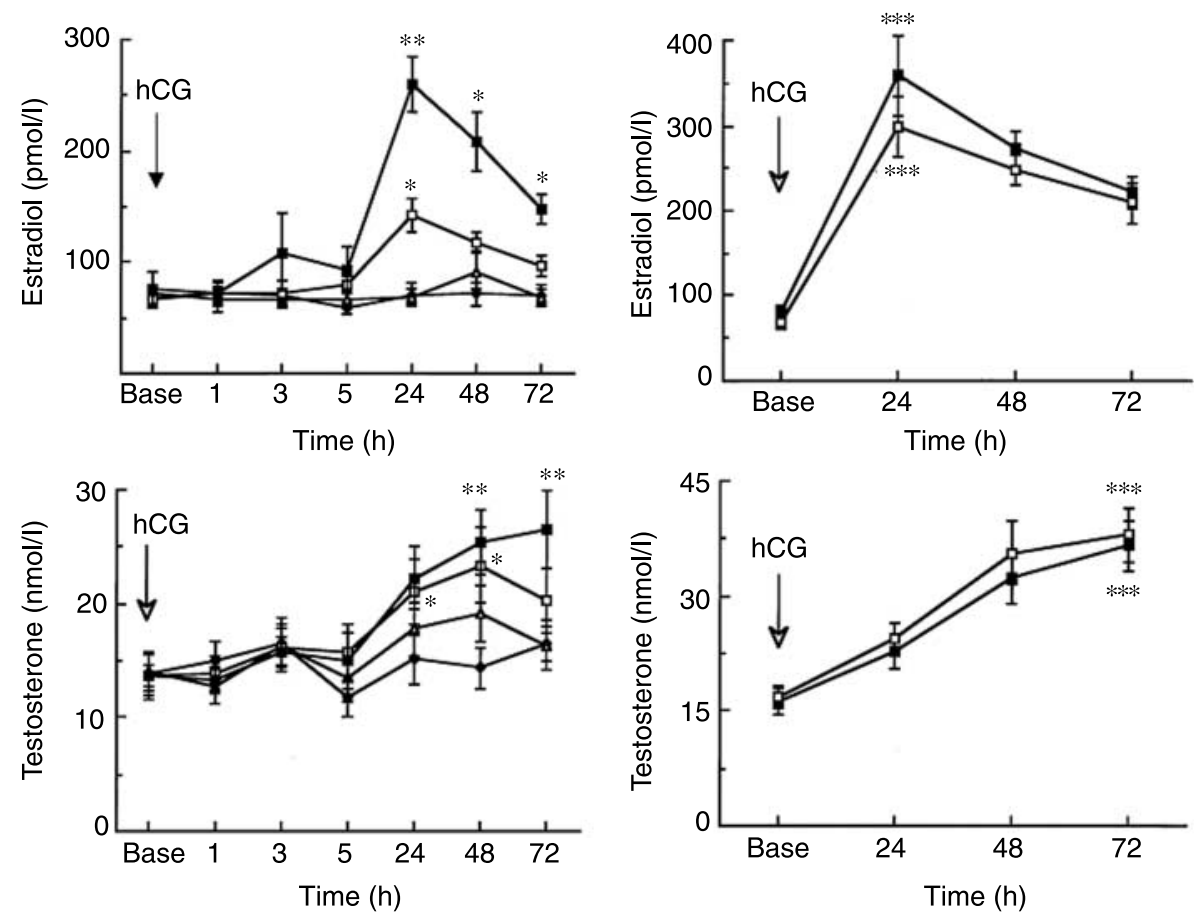

Figure 1 Left column: mean \pm S.E.M. of plasma estradiol (upper panel) and testosterone levels (lower panel) in normal men (group I) in response to the injection of vehicle alone $(\star)$ or $50(\triangle), 500(\square)$, and $5000 \mathrm{IU}(\boldsymbol{\square})$ ehCG. Statistical significance: ${ }^{\star} P<0.05$, ${ }^{\star \star} P<0.01$. Right column: mean \pm S.E.M. of plasma estradiol (upper panel) and testosterone levels (lower panel) in normal men (group II) in response to the injection of either 5000 IU ehCG $(\square)$ or 6500 IU rhCG (ם). Statistical significance: ${ }^{\star \star \star} P<0.001$. 

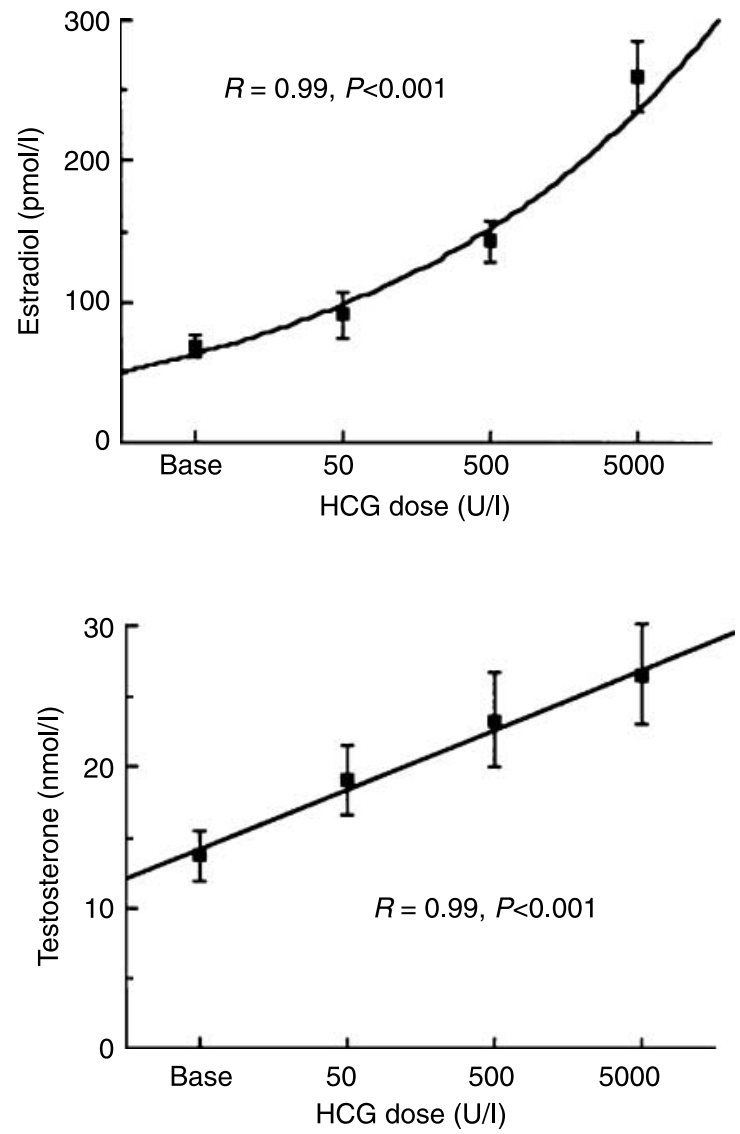

Figure 2 Dose-effect relationship between hCG dose and $E_{2}$ (upper panel) and T (lower panel) peak response (mean \pm S.E.M.) to the stimulation.

significantly higher $(P<0.01)$ than that observed with 500 IU hCG.

There were clear dose-effect relationships between the doses of hCG used and the peak responses of both T and $\mathrm{E}_{2}$ (Fig. 2).

\section{Group II}

Mean basal plasma $\mathrm{T}$ levels were $16.75 \pm 1.49$ and $16.23 \pm 1.70 \mathrm{nmol} / \mathrm{l}$ before the injection of $5000 \mathrm{IU}$ ehCG and 6500 IU rhCG respectively. They rose to $38.10 \pm 3.74$ and $36.61 \pm 3.40 \mathrm{nmol} / \mathrm{l} 72 \mathrm{~h}$ after the respective injection of 5000 IU ehCG and 6500 IU rhCG. These two peaks did not differ but were significantly $(P<0.001)$ higher than their respective basal values (Fig. 1).

Mean basal plasma $E_{2}$ levels were $67.91 \pm 6.61$ and $80.02 \pm 8.07 \mathrm{pmol} / \mathrm{l}$ before the injection of $5000 \mathrm{IU}$ ehCG and $6500 \mathrm{IU}$ rhCG respectively. They rose to $297.72 \pm 35.61$ and $358.29 \pm 46.62 \mathrm{pmol} / \mathrm{l} 24 \mathrm{~h}$ after the respective injection of $5000 \mathrm{IU}$ ehCG and $6500 \mathrm{IU}$ rhCG. These two peaks did not differ but were significantly $(P<0.001)$ higher than their respective basal values (Fig. 1).

Mean basal plasma LH level was $3.7 \pm 0.4 \mathrm{U} / \mathrm{l}$ on the testing using vehicle alone. Similar basal plasma $\mathrm{LH}$ levels were obtained before the injection of the different doses of rhLH (Table 2). Plasma LH levels did not vary after vehicle injection. By contrast, they increased to $28.3 \pm 6.7,53.1 \pm 16.7$, and $41.9 \pm 8.2 \mathrm{U} / \mathrm{l}$ after the injection of 75,150 , and $225 \mathrm{IU}$ rhLH respectively. The peak value was obtained $30 \mathrm{~min}$ after rhLH injection. Then, plasma LH levels progressively dropped to reach basal values $6 \mathrm{~h}$ later (Fig. 3).

Before testing with rhLH, mean basal plasma T level was $16.88 \pm 1.90 \mathrm{nmol} / \mathrm{l}$. Similar basal plasma T levels were obtained before the injection of the different doses of rhLH (Table 2). Plasma $\mathrm{T}$ progressively declined to $14.14 \pm 1.66 \mathrm{nmol} / \mathrm{l} 5 \mathrm{~h}$ after the injection of placebo. By contrast, they increased to $17.92 \pm 1.98,18.72 \pm$ 2.18 , and $19.21 \pm 1.70 \mathrm{nmol} / \mathrm{l}$ during the same time after the i.v. injection of 75,150 , and $225 \mathrm{IU}$ rhLH respectively (Fig. 3). By comparison with the placebo testing, there were statistically significant differences (at least $P<0.03$ ) in mean $\mathrm{T}$ plasma levels on times 180 , 240 , and $300 \mathrm{~min}$ following rhLH injection. The statistical highest difference $(P<0.001)$ was observed at the time $+300 \mathrm{~min}$ after injection of $225 \mathrm{IU}$ rhLH.

There was a clear dose-effect relationship between the doses of rhLH used and the highest plasma T level reached after stimulation (Fig. 4). The highest plasma T levels attained after the injection of either 150 or $225 \mathrm{IU}$ rhLH were significantly $(P<0.01$ and $P<0.05$ respectively) correlated with the peak increase in $\mathrm{T}$ in response to the injection of $250 \mu \mathrm{g}$ rhCG (Fig. 4).

In contrast to $\mathrm{T}$, no significant difference was observed at any time in plasma $\mathrm{E}_{2}$ levels whatever rhLH dose was used (Fig. 3).

Table 2 Basal and peak values of plasma luteinizing hormone (LH) and testosterone (mean \pm S.E.M.) in normal men (group II) in response to the injection of vehicle alone or 75, 150, and 225 IU recombinant human LH (rhLH).

\begin{tabular}{lcccc}
\hline & LH base $(\mathrm{U} / \mathrm{l})$ & LH peak $(\mathrm{U} / \mathrm{l})$ & $\begin{array}{c}\text { Testosterone base } \\
(\mathrm{nmol} / \mathrm{l})\end{array}$ & $\begin{array}{c}\text { Testosterone peak } \\
(\mathrm{nmol} / \mathrm{l})\end{array}$ \\
\hline Vehicle & $3.7 \pm 0.4$ & $2.9 \pm 0.3$ & $16.9 \pm 1.9$ & $14.1 \pm 1.7$ \\
75 IU rhLH & $4.0 \pm 0.4$ & $28.0 \pm 6.7$ & $16.5 \pm 1.9$ & $17.9 \pm 2.0$ \\
150 IU rhLH & $4.0 \pm 0.6$ & $53.1 \pm 16.7$ & $16.5 \pm 1.8$ & $18.7 \pm 2.2$ \\
225 IU rhLH & $3.8 \pm 0.5$ & $41.9 \pm 8.2$ & $17.4 \pm 1.8$ & $19.2 \pm 1.7$ \\
\hline
\end{tabular}



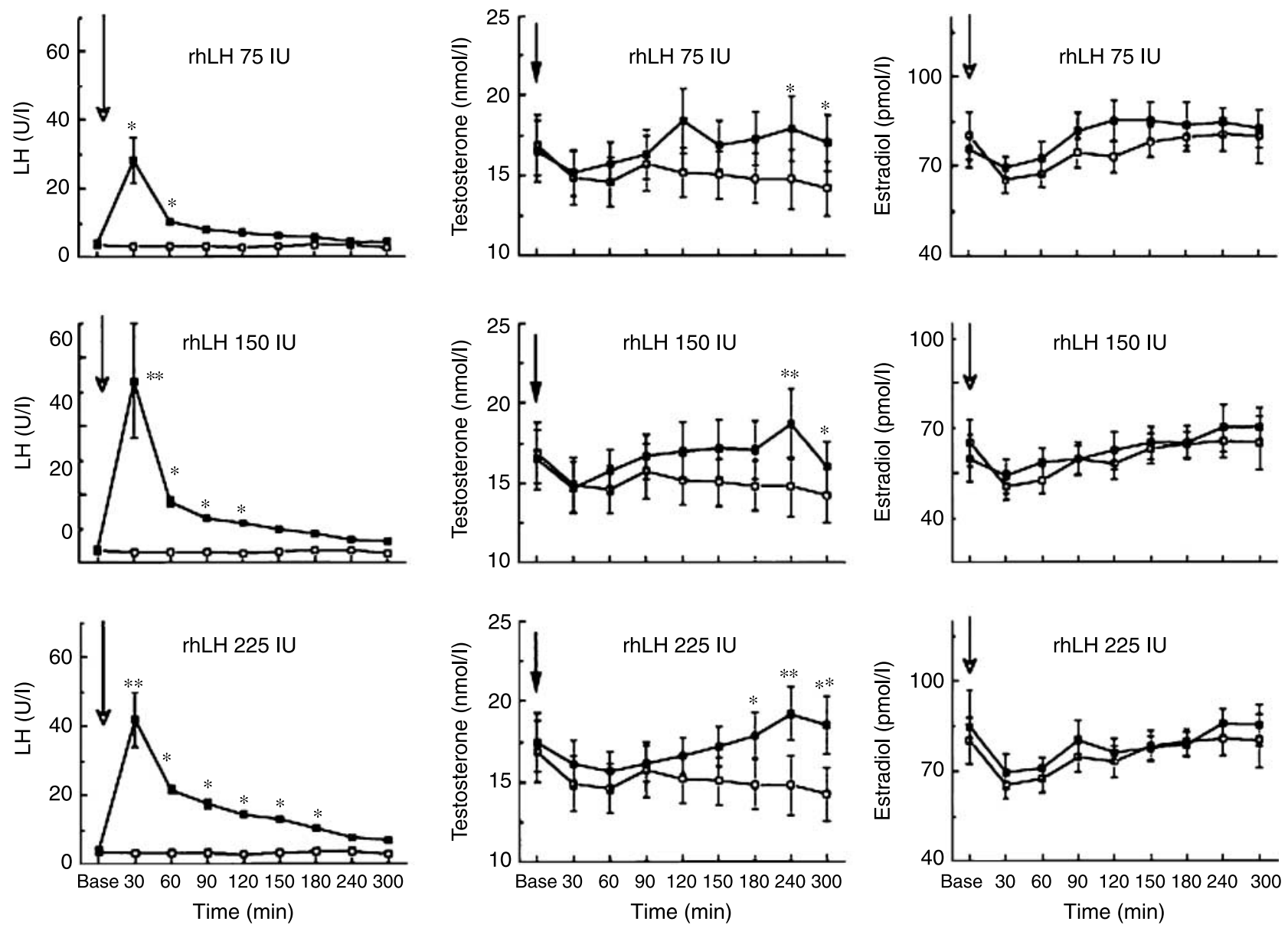

Figure 3 Left column: plasma LH (mean \pm S.E.M.) in normal men (group II) in response to the injection of vehicle alone $(\square)$ or 75 , 150, and $225 \mathrm{IU}$ rhLH ( $\mathbf{\square})$. Middle column: plasma testosterone (mean \pm s.E.m.) in normal men in response to the injection of vehicle alone ( $\square$ ) or 75 , 150, and $225 \mathrm{IU}$ rhLH ( $\square$ ). Right column: plasma estradiol (mean \pm S.E.M.) in normal men in response to the injection of vehicle alone ( $\square$ ) or 75, 150, and $225 \mathrm{IU}$ rhLH ( $\mathbf{\square})$. Statistical significance: ${ }^{\star} P<0.05,{ }^{\star \star} P<0.01$.

\section{Discussion}

The effects of an acute injection of ehCG on the yield of $\mathrm{T}$ and $\mathrm{E}_{2}$ are well demonstrated in animal and man $(16,17,21)$. In normal adult men, plasma $\mathrm{E}_{2}$ and $\mathrm{T}$ levels reach a peak 24 and $72 \mathrm{~h}$ respectively after a single i.m. injection of a pharmacological dose (1500$5000 \mathrm{IU})$ of ehCG $(12,14,15,17-19,22)$. The stimulating effect of ehCG, mediated through the activation of the LH/hCG receptor of the Leydig cell, involves the amplification of the enzymatic pathways of sex steroid synthesis. Furthermore, a gonadotropininduced activation of Leydig cell aromatase leads to a rise in $\mathrm{E}_{2}$ synthesis $(14,17,23)$. Multiple injections of ehCG give similar results as a single one $(16,24,25)$. A prolonged exposure to elevated doses of hCG induces a desensitization process in rat and man $(22,26,27)$. Such a phenomenon is observed in men with hCG-secreting tumors (28-30). The desensitization occurs as soon as $24 \mathrm{~h}$ after ehCG injection and modifies the testicular hormone response. It stems from both a stimulation through the activation of the membrane LH/hCG receptor as well as a transient downregulation of these receptors (30-32). As a result of these combined events, the testicular response to ehCG shows a biphasic pattern with an initial testosterone rise within $12 \mathrm{~h}$, followed by decline $(3,33,34)$. Then, a second testosterone peak appeared 48-72 $\mathrm{h}$ after the stimulation (33-35). By contrast, this biphasic response does not occur with LH, which may account for various factors. They include respective plasma half lives of the hormones: short for $\mathrm{LH}$, prolonged for hCG $(1,2)$; reversibility of the binding to the receptor: possible for LH, not possible for hCG $(36,37)$; and pattern of plasma levels: pulsatile for $\mathrm{LH}$ and sustained for hCG. With the aim of shortening the testing and to limit the drawbacks of the desensitization process, we initially studied the effect of lower doses of ehCG than that actually used. Hormone levels were measured on the early and then usual times of evaluation of the Leydig cell response to the stimulation.

The injection of the lowest dose of ehCG (50 IU) was not followed by any steroid hormone change. By contrast, the injection of $500 \mathrm{IU}$ induced significant increases in plasma $\mathrm{E}_{2}$ and $\mathrm{T}$ levels that peaked 

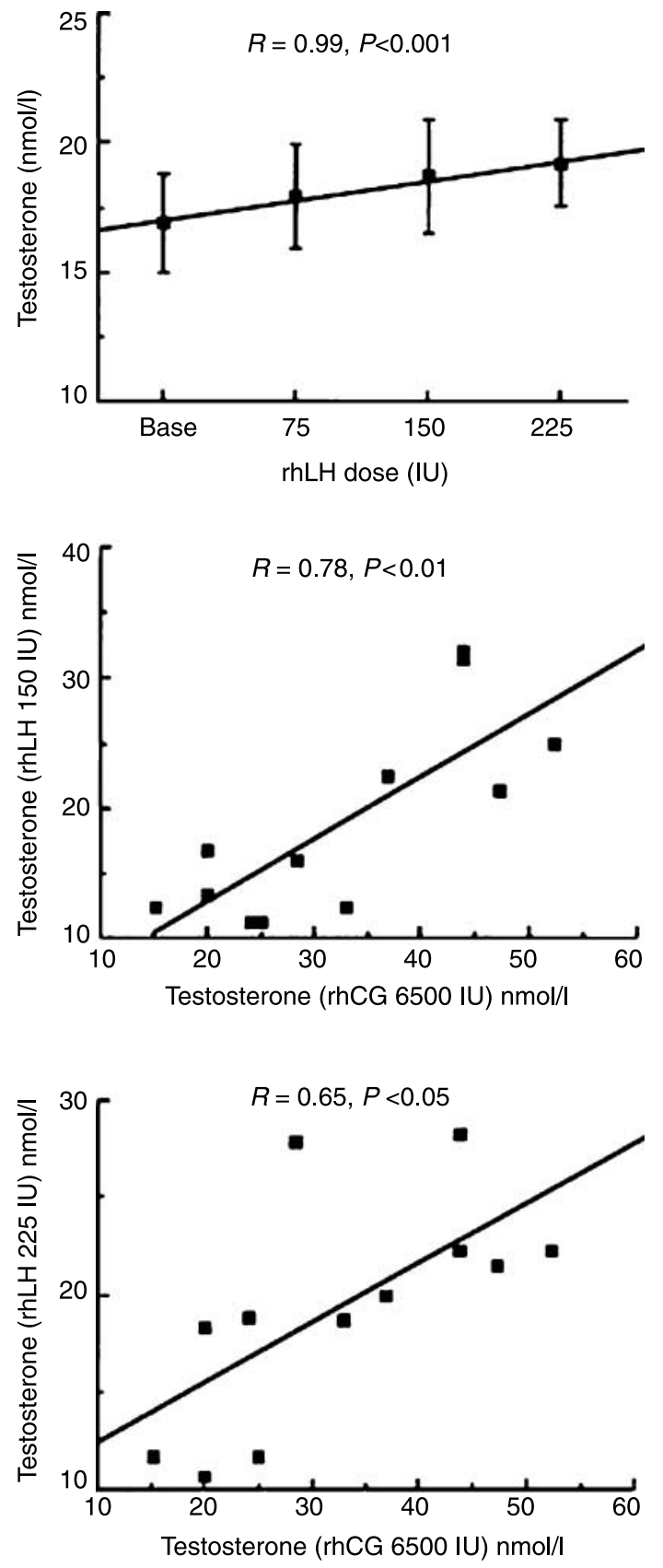

Figure 4 Left part: dose-effect relationship between rhLH dose and $T$ peak response (mean \pm S.E.M.) to the stimulation. Right part: correlations observed between the peak responses of T to $250 \mu \mathrm{g}$ (6500 IU) rhCG and the highest plasma T levels reached after injection of either $150 \mathrm{IU}$ (higher panel) or $225 \mathrm{IU}$ rhLH (lower panel).

respectively 24 and $48 \mathrm{~h}$ later. Even though peaks reached were significantly higher than with $500 \mathrm{IU}$ ehCG, similar patterns of response of both steroid hormones were observed using $5000 \mathrm{IU}$ ehCG. These results suggest that, without consideration of the ehCG dose used, the most relevant times of testing are $+24 \mathrm{~h}$ for $\mathrm{E}_{2}$ and $+48 \mathrm{~h}$ for $\mathrm{T}$ measurements. As evidenced by the dose-effect relationship, 5000 IU ehCG should be preferred to lower doses. Indeed, the hCG-induced $\mathrm{E}_{2}$ rise was significantly higher with 5000 IU ehCG. Using this dose would allow limitation of the testing to $48 \mathrm{~h}$. Relevant hormone measurements could be plasma $\mathrm{E}_{2}$ level at time $+24 \mathrm{~h}$ and/or T level at time $+48 \mathrm{~h}$ after ehCG injection, which agree with previously published data $(16,18,19,34)$. Indeed, plasma T levels measured at times $+48 \mathrm{~h}$ and $+72 \mathrm{~h}$ did not significantly differ and very likely gave the same information to the clinician.

Available recombinant hCG will logically replace ehCG for treatments and endocrine testing. Thus, we evaluated the effects of recombinant human chorionic gonadotropin (rhCG, packaged as $250 \mu \mathrm{g}=6500 \mathrm{IU}$ ) in comparison with that of ehCG (5000 IU) in the same healthy volunteers. The amplitude of steroid rises and the patterns of change were similar between the two tests. On the basis of the results of the present study, we can offer as a standard testing the i.m. injection of $250 \mu \mathrm{g}$ (6500 IU) rhCG after a basal blood drawing and then the measurement of plasma $\mathrm{E}_{2}$ levels $24 \mathrm{~h}$ later and/or plasma T levels at time $+48 \mathrm{~h}$.

The effects of i.v. rhLH, administered in different doses, were studied in the same healthy men. We searched to specify if rhLH could be used as a stimulus as relevant as rhCG to test the Leydig cell function. The objectives were to develop a shorter and more physiological dynamic testing of the endocrine testis. A paradigm using a previous gonadotroph desensitization with GnRH analogs would have led to more clear changes in plasma $\mathrm{T}$ levels in response to rhLH but would have been far from physiology. For this reason, we chose to study the responses to rhLH without any modulation of gonadotropin secretion. Obviously, rhLH injection at any dose was followed by a stimulation of $\mathrm{T}$ secretion. By comparison with the spontaneous physiological decrease in plasma $\mathrm{T}$ during morning, T progressively rose to a highest value obtained $4 \mathrm{~h}$ after rhLH i.v. administration. This agrees with the data obtained by several authors who used repeated rhLH pulse infusion in normal men (38-40). The injection of rhLH not only induced a $12 \%$ rise in mean plasma $\mathrm{T}$ from basal levels but also acted against the physiological decline in plasma $\mathrm{T}$ levels that spontaneously decreased by $15 \%$ between 0800 and $1200 \mathrm{~h}$. As to whether there was a linear relationship between the highest plasma $\mathrm{T}$ value reached and the injected dose of rhLH, statistically similar results were obtained with 150 and $225 \mathrm{IU}$ rhLH. Interestingly, plasma $\mathrm{T}$ levels measured $240 \mathrm{~min}$ after rhLH injection were significantly correlated with the peak of $\mathrm{T}$ obtained $48 \mathrm{~h}$ after the stimulation with rhCG. Despite the differences in both bioavailability and time courses of action of rhLH and hCG given by different routes, the 'response' to an acute i.v. rhLH injection could hence be a reflection of the responsiveness of testicular Leydig cell to a maximal stimulation with rhCG. In contrast to T, no rhLH-induced change was observed in plasma $\mathrm{E}_{2}$ levels. This probably results in a lesser potency of the stimulation with LH rather than with hCG, likely 
explained by the short plasma half life of rhLH and the reversibility of its binding to the $\mathrm{LH} / \mathrm{hCG}$ receptor (41). On the basis of the present study, a short testing of endocrine testicular function might be proposed. The design could be the following: a blood drawing for a basal T measurement has to be performed at midday on day 1 of the test. On day 2 at $0800 \mathrm{~h}, 150 \mathrm{IU}$ rhLH should be injected intravenously. After $4 \mathrm{~h}$, a second blood drawing has to be done to measure plasma T levels. By comparison with day 1 , a rise by $25 \%$ of plasma Ton day 2 is observed in healthy normal men. Although rhLH represents a more physiological tool than hCG to test the endocrine testis, the results obtained with rhLH in the present study need to be confirmed in a larger series of men and compared with that of the patients with delayed puberty or hypogonadism using the same study design. However promising, these results are preliminary and suggest that, at the moment, the use of rhCG should be kept as a gold standard for the evaluation of Leydig cell function. The measurement of either $\mathrm{E}_{2}$ or $\mathrm{T}$ respectively at 24 and $48 \mathrm{~h}$ after the i.m. injection of $250 \mu \mathrm{g}$ (6500 IU) rhCG, appears like a good design as it gives similar results than 5000 IU ehCG.

In conclusion, a single i.v. injection of $150 \mathrm{IU}$ rhLH in normal adult men induces a $25 \%$ rise in plasma $\mathrm{T}$ levels by comparison with the reference day. The results do not permit the proposition of a very short testing of steroid hormone secretion of the testis as $\beta_{1-24}$ ACTH test for adrenal gland. However, confirmed in a larger series of men, they would lead to considering the elaboration of a short and cheap testing of Leydig cell function with two blood drawings separated by $24 \mathrm{~h}$ and flanking a single i.v. injection of $150 \mathrm{IU}$ rhLH. At the moment, hCG testing remains the gold standard for the dynamic evaluation of the endocrine testis. Recombinant hCG at a dose of $250 \mu \mathrm{g}$ (6500 IU) gives the same results as 5000 IU extractive hCG. After a basal blood drawing, the measurement of $\mathrm{E}_{2}$ or T respectively at 24 and $48 \mathrm{~h}$ after the injection of rhCG gives pertinent information on the steroid hormone secretion of the adult testis.

\section{Acknowledgements}

We would like to acknowledge Mr S Eiffler for his help to realize this study, Mrs O Vandapel for her technical assistance, and Mrs C Boulard, L Gutierrez and C Schaffter for their efficient role in performing this study. The study was supported by grants from University Hospital of Rouen and from INSERM CIC 204, Rouen, France.

\section{References}

1 Yen SCC, Iberena O, Little B \& Pearson OH. Disappearance rates of endogenous luteinizing hormone and chorionic gonadotropin in man. Journal of Clinical Endocrinology and Metabolism 196828 1763-1768.
2 Veldhuis JD, Fraioli F, Rogol AD \& Dufau ML. Metabolic clearance of biologically active luteinizing hormone in man. Journal of Clinical Investigation 198677 1122-1128.

3 Padron RS, Wischusen J, Hudson B, Burger HG \& de Kretzer DM. Prolonged biphasic response of plasma testosterone to single intramuscular injections of human chorionic gonadotropin. Journal of Clinical Endocrinology and Metabolism $1980501100-1104$.

4 Trinchard-Lugan I, Khan A, Porchet HC \& Munfano A. Pharmacokinetics and pharmacodynamics of recombinant human chorionic gonadotrophin in healthy male and female volunteers. Reproductive Biomedicine Online 20024 106-115.

5 Hoorweg-Nijman JJ, Havers HM \& Delemarre-van de Waal HA. Effect of human chorionic gonadotrophin (hCG)/follicle-stimulating hormone treatment versus hCG treatment alone on testicular descent: a double-blind placebo-controlled study. European Journal of Endocrinology 1994130 60-64.

6 Davenport M, Brain C, Vandenberg C, Zappala S, Duffy P, Ransley PG \& Grant D. The use of the hCG stimulation test in the endocrine evaluation of cryptorchidism. British Journal of Urology $1995 \mathbf{7 6} 790-794$.

7 McEachern R, Houle AM, Garel L \& Van Vliet G. Lost and found testes: the importance of the hCG stimulation test and other testicular markers to confirm a surgical declaration of anorchia. Hormone Research 200462 124-128.

8 Kirk JM, Savage MO, Grant BD, Bouloux PM \& Besser GM. Gonadal function and response to human chorionic and menopausal gonadotrophin therapy in male patients with idiopathic hypogonadotrophic hypogonadism. Clinical Endocrinology $1994 \mathbf{4 1}$ 57-63.

9 Kliesch S, Behre HM \& Nieschlag E. Recombinant human folliclestimulating hormone and human chorionic gonadotropin for induction of spermatogenesis in a hypogonadotropic male. Fertility and Sterility 199563 1326-1328.

10 Liu PY, Turner L, Rushford D, McDonald J, Baker HW, Conway AJ \& Handelsman DJ. Efficacy and safety of recombinant human follicle stimulating hormone (Gonal-F) with urinary human chorionic gonadotrophin for induction of spermatogenesis and fertility in gonadotrophin-deficient men. Human Reproduction 199914 1540-1545.

11 Kauschansky A, Dickerman Z, Phillip M, Weintrob N \& Strich D. Use of GnRH agonist and human chorionic gonadotrophin tests for differentiating constitutional delayed puberty from gonadotropin deficiency in boys. Clinical Endocrinology 200256 603-607.

12 Degros V, Cortet-Rudelli C, Soudan B \& Dewailly D. The human chorionic gonadotropin test is more powerful than the gonadotropin-releasing hormone agonist test to discriminate male isolated hypogonadotropic hypogonadism from constitutional delayed puberty. European Journal of Endocrinology 2003149 23-29.

13 Martin MM \& Martin AL. Constitutional delay of puberty in males and hypogonadotropic hypogonadism: a reliable and cost-effective approach to differential diagnosis. Journal of Pediatric Endocrinology and Metabolism 200518 909-916.

14 Kuhn JM, Mahoudeau JA, Billaud L, Joly J, Rieu M, Gancel A, Archambeau-Mouveroux F, Steg A \& Luton JP. Evaluation of diagnosis criteria for Leydig cell tumours in adult men revealed by gynecomastia. Clinical Endocrinology 198726 407-416.

15 Kuhn JM, Reznik Y, Mahoudeau JA, Coutois H, Lefebvre H, Wolf LM \& Luton JP. hCG test in gynecomastia: further studies. Clinical Endocrinology 198931 581-590.

16 Smals AG, Pieters GF, Drayer JIM, Benraad TJ \& Kloppenborg PWC. Leydig cell responsiveness to single and repeated human chorionic gonadotropin administration. Journal of Clinical Endocrinology and Metabolism $19794912-14$.

17 Mahoudeau JA, Valcke JC \& Bricaire H. Dissociated responses of plasma testosterone and estradiol to human chorionic gonadotropin in adult men. Journal of Clinical Endocrinology and Metabolism $1975 \mathbf{4 1} 13-20$.

18 Levalle OA, Suescun MO, Fiszlejder L, Aszpis S, Charreau E, Guitelman A \& Calandra R. Effect of an antiestrogen on the 
testicular response to acute and chronic administration of hCG in normal and hypogonadotropic hypogonadism men: tamoxifen and testicular response to hCG. Andrologia 199123 109-114.

19 Meier C, Christ-Crain M, Christoffel-Courtin C, Staub JJ \& Muller B. Serum estradiol after a single dose hCG administration correlates with Leydig cell reserve in hypogonadal men: reassessment of hCG stimulation test. Clinical Laboratory 200551 509-515.

20 Talbot JA, Mitchell R, Hoy AM, Lambert A, Gauher A, Hilton B, McLoughlin JD \& Robertson WR. Recombinant human luteinizing hormone: a partial physico-chemical, biological and immunological characterization. Molecular Human Reproduction 19962 799-806.

21 Weinstein RL, Kelch RP, Jenner MR, Kaplan SL \& Grumbach MM. Secretion of unconjugated androgens and estrogens by the normal and abnormal human testis before and after human chorionic gonadotropin. Journal of Clinical Investigation 1974 53 1-14.

22 Saez JM, Haour F, Tell GEP, Gallet D \& Sanchez P. Human chorionic gonadotropin-induced Leydig cell refractorines to gonadotropin stimulation. Molecular Pharmacology 197814 1054-1056.

23 Valladares LE, Sarkar D \& Payne AH. Induction of aromatase by hCG in testis of adult rats. Endocrinology $1978 \mathbf{1 0 2} 138-142$.

24 Dunkel L, Perheentupa J \& Sorva R. Single versus repeated dose human chorionic gonadotropin stimulation in the differential diagnosis of hypogonadotropic hypogonadism. Journal of Clinical Endocrinology and Metabolism $198560333-337$.

25 Kolon TF \& Miller OF. Comparison of single versus multiple dose regimens for the human chorionic gonadotropin stimulation test. Journal of Urology 2001166 1451-1454.

26 Haour F \& Saez JM. Regulation of hCG of gonadotropin receptors in testicular Leydig cells: evidence for a down regulation. Molecular and Cellular Endocrinology 19787 17-23.

27 Tell GP, Haour F \& Saez JM. Hormonal regulation of membrane receptors and cell responsiveness: a review. Metabolism 197927 1566-1573.

28 Kirschner MA, Wider JA \& Ross GT. Leydig cell functions in men with gonadotrophin-producing testicular tumours. Journal of Clinical Endocrinology and Metabolism 197030 504-511.

29 Reznik Y, Rieu M, Kuhn JM, Mandard JC, Bottet P, Lemonnier D, Bekka $S$ \& Mahoudeau J. Luteinizing hormone regulation by sex steroids in men with germinal and Leydig cell tumours. Clinical Endocrinology 199338 487-493.

30 Rieu M, Reznik Y, Vannetzel JM, Mahoudeau J, Berrod JL \& Kuhn JM. Testicular steroidogenesis in adult men with human chorionic gonadotropin-producing tumors. Journal of Clinical Endocrinology and Metabolism 199580 2404-2409.

31 Sharpe RM. HCG-induced decrease in availability of rat testis receptors. Nature $1976 \mathbf{2 6 4} 644-646$.
32 Tsuruhara T, Dufau ML, Cigorraga S \& Catt KJ. Hormonal regulation of testicular luteinizing hormone receptors: effects on cyclic AMP and testosterone responses in isolated Leydig cells. Journal of Biological Chemistry 1977262 9002-9009.

33 Smals AG, Pieters GF, Kloppenborg PW, Lozekoot DC \& Benraad TJ. Lack of biphasic response to single human chorionic gonadotropin administration in patients with isolated gonadotropin deficiency. Journal of Clinical Endocrinology and Metabolism 198050 879-881.

34 Balducci R, Adamo MV, Mangiantini A, Municchi G \& Toscano V. Testicular responsiveness to a single dose in patients with testicular feminization. Hormone and Metabolic Research 198921 449-452.

35 Saez JM \& Forest MG. Kinetics of human chorionic gonadotropininduced steroidogenic response of the human testis. I. Plasma testosterone: implications for human chorionic gonadotropin stimulation test. Journal of Clinical Endocrinology and Metabolism $197949278-283$.

36 Catt KJ, Tsuruhara T, Mendelson C, Ketelslegers JM \& Dufau ML. Gonadotropin binding and activation of interstitial cells of the testis. Current Topics in Molecular Endocrinology 19741 1-30.

37 Dufau ML \& Catt KJ. Gonadotropin receptors and regulation of steroidogenesis in testis and ovary. Vitamins and Hormones 1978 36 461-585.

38 Mulligan T, Iranmanesh A \& Veldhuis JD. Pulsatile IV infusion of recombinant human $\mathrm{LH}$ in leuprolide-suppressed men unmasks impoverished Leydig-cell secretory responsiveness to midphysiological LH drive in the aging male. Journal of Clinical Endocrinology and Metabolism $2001 \mathbf{8 6} 5547-5553$.

39 Veldhuis JD \& Iranmanesh A. Pulsatile intravenous infusion of recombinant human luteinizing hormone under acute gonadotropin-releasing hormone receptor blockade reconstitues testosterone secretion in young men. Journal of Clinical Endocrinology and Metabolism 200489 4474-4479.

40 Veldhuis JD, Veldhuis NJD, Keenan DM \& Iranmanesh A. Age diminishes the testicular steroidogenic response to repeated intravenous pulses of recombinant human LH during acute GnRH-receptor blockade in healthy men. American Journal of Physiology. Endocrinology and Metabolism 2005288 E775-E781.

41 Gromoll J, Eiholzer U, Nieschlag E \& Simoni M. Male hypogonadism caused by homozygous deletion of exon 10 of the luteinizing hormone (LH) receptor: differential action of human chorionic gonadotropin and LH. Journal of Clinical Endocrinology and Metabolism 200085 2281-2286.

Received 27 March 2008

Accepted 16 May 2008 